\title{
Striatal Excitatory Amino Acid Transporter Transcript Expression in Schizophrenia, Bipolar Disorder, and Major Depressive Disorder
}

\author{
Robert E. McCullumsmith, M.D., Ph.D., and James H. Meador-Woodruff, M.D.
}

Because abnormalities of glutamatergic neurotransmission in psychiatric illness are likely not limited to glutamate receptor expression, we investigated expression of excitatory amino acid transporters (EAATs) in the striatum. The EAATs, normally expressed in both glia (EAAT1 and EAAT2) and neurons (EAAT3 and EAAT4), have previously been implicated in Huntington's disease, amyotrophic lateral sclerosis, and schizophrenia. In this study, we investigated striatal expression of transcripts encoding EAATs in tissue from mood disordered and schizophrenic subjects. With probes designed for the human EAAT1, EAAT2, EAAT3, and EAAT4 transcripts, we performed in situ hybridization and detected decreased expression of EAAT3 and EAAT4 transcripts in the striatum in bipolar disorder. We also detected decreased EAAT3 transcript expression in schizophrenia and decreased EAAT4 transcript expression in major depressive disorder. These results suggest that changes in striatal transporter $m R N A$ expression are restricted to neuronal EAATs and extend the body of evidence implicating abnormal glutamatergic neurotransmission in schizophrenia and mood disorders.

[Neuropsychopharmacology 26:368-375, 2002] (C) 2002 American College of Neuropsychopharmacology. Published by Elsevier Science Inc.
KEY WORDS: Glutamate, Striatum, Mood disorder, Antidepressant, Mood stabilizer, Affective disorder

A growing literature suggests abnormal expression of ionotropic glutamate receptors in the brain in schizophrenia. The preponderance of these studies has detected complex and regionally specific alterations in $\alpha$-amino3-hydroxy-5-methyl-4-isoxazolepropionate (AMPA), kain-

From the Mental Health Research Institute and Department of Psychiatry, University of Michigan, Ann Arbor, MI

Address correspondence to: Robert E. McCullumsmith, M.D. Ph.D., Mental Health Research Institute and Department of Psychiatry, University of Michigan, 205 Zina Pitcher Place, Ann Arbor, MI 48109-0720; Tel.: 734-936-2061; E-mail: smithrob@umich.edu

Received April 30, 2001; revised August 22, 2001; accepted September 7, 2001.

Online publication: $9 / 17 / 01$ at www.acnp.org/citations/ Npp091701177. ate, and N-methyl-D-aspartate (NMDA) receptor expression, especially in cingulate cortex and medial temporal lobe structures (Akbarian et al. 1996; Aparicio-Legarza et al. 1998; Deakin et al. 1989; Eastwood et al. 1997a, 1997b, 1995; Grimwood et al. 1999; Harrison et al. 1991; Healy et al. 1998; Humphries et al. 1996; Ibrahim et al. 2000; Kerwin et al. 1988, 1990; Kornhuber et al. 1989; MeadorWoodruff and Healy 2000; Nishikawa et al. 1983; Noga et al. 1997; Ohnuma et al. 1998; Porter et al. 1997; Sokolov 1998). Recently, such studies have been extended to other brain regions associated with limbic circuitry felt to be disturbed in psychiatric illnesses, including the striatum. Increased NMDA receptor binding at both the glycine/D-serine coagonist site and the intrachannel MK801 site was detected in the putamen, and increased CNQX (an AMPA/kainate antagonist) binding was detected in the caudate in schizophrenia (Aparicio-Legarza et al. 
1998; Kornhuber et al. 1989). In bipolar disorder, decreased GluR1 mRNA expression was detected in the striatum (Meador-Woodruff et al. 2001). Based on the finding of alterations in glutamate receptor expression in the striatum, we hypothesize that other components of the glutamate synapse may be abnormal as well. Candidates for such an abnormality include the family of excitatory amino acid transporters (EAATs), a group of molecules essential for normal glutamatergic neurotransmission (Sims and Robinson 1999).

The family of glutamate/aspartate transporters has five members (EAAT1, EAAT2, EAAT3, EAAT4, and EAAT5) that are similar to the neutral amino acid transporters ASCT1 and ASCT2 (Arriza et al. 1993; Utsunomiya-Tate et al. 1996). The transporters have specific patterns of cellular localization: EAAT1 and EAAT2 have been localized to astroglia, whereas EAAT3 and EAAT4 are localized to neurons (Bar-Peled et al. 1997; Chaudhry et al. 1995; Furuta et al. 1997; Lehre et al. 1995; Milton et al. 1997; Rothstein et al. 1994; Sims and Robinson 1999; Yamada et al. 1996, 1997). The best studied of the glutamate transporters, EAAT2 (called GLT-1 in the rat) accounts for $\sim 90 \%$ of forebrain glutamate reuptake in the rodent (Rothstein et al. 1996; Tanaka et al. 1997). The predominately glial expression of EAAT2 mRNA and protein, observed throughout the human brain, is highest in the forebrain (Bar-Peled et al. 1997; Milton et al. 1997). Similar to EAAT2, EAAT3 (called EAAC1 in the rat) protein expression in the human brain is detected in the frontal cortex and the hippocampus (Bar-Peled et al. 1997). EAAT3 is localized to both post- and presynaptic neuronal soma and is associated with $\sim 40 \%$ of rodent hippocampal glutamate transport (Rothstein et al. 1994). In contrast, levels of EAAT1 (called GLAST in the rat) and EAAT4 protein expression in the rodent central nervous system (CNS) are highest in the cerebellum in the Bergmann glia and Purkinje cell types, respectively, whereas human studies of EAAT1 protein expression indicate high levels in the frontal cortex (Rothstein et al. 1994; Yamada et al. 1996, 1997). CNS EAAT5 mRNA expression is limited to the retina (Arriza et al. 1997).

Studies of EAAT knockout mice demonstrate the potential clinical significance of abnormalities of EAAT expression. GLT-1 (EAAT2) knockout animals develop lethal seizures, whereas GLAST (EAAT1) knockout animals have subtler defects, including difficulties with coordination (Rothstein et al. 1996; Tanaka et al. 1997; Watase et al. 1998). Not surprisingly, alterations in EAAT expression have been detected in epilepsy, Huntington's disease, and amyotrophic lateral sclerosis (Arzberger et al. 1997; Fray et al. 1998; Lin et al. 1998; Meyer et al. 1998, 1999; Ohnuma et al. 1998). Thus, we hypothesize that an abnormality in striatal EAAT expression may contribute to glutamatergic dysfunction in psychiatric diseases. The aim of this study was to in- vestigate striatal expression of members of the family of EAATs (EAAT1, EAAT2, EAAT3, and EAAT4) in bipolar disorder, schizophrenia, and major depressive disorder (MDD).

\section{MATERIALS AND METHODS}

\section{Subjects}

Postmortem brains from 60 subjects from the Stanley Foundation Neuropathology Consortium were studied, comprising four groups of 15 subjects each with diagnoses of schizophrenia, bipolar disorder, MDD, and a comparison group. A summary of a recently published detailed description of this collection is shown in Table 1 (Torrey et al. 2000). Brain specimens from the four treatment groups were processed simultaneously, and sections were matched for anatomical level by gross anatomical landmarks. Cryostat-sectioned $(14-\mu \mathrm{m})$ slides from the fresh frozen half of these brains were stored at $-80^{\circ} \mathrm{C}$ until used.

\section{In Situ Hybridization}

The design of this study was to examine striatal expression of the transcripts encoding EAAT1, EAAT2, EAAT3, and EAAT4. To generate subclones for riboprobe synthesis, we amplified unique regions of EAAT1 (NCBI Genebank accession \# U03504, nucleotide coding region 526-825), EAAT2 (NM004171, 601-1026), EAAT3 (NM004170, 156-979), and EAAT4 (NM005071, 541900) from a human cDNA brain library (EdgeBiosystems, Gaithersburg, MD) using polymerase chain reaction (PCR). For EAAT2, the region selected is common to all known splice variants. Amplified cDNA segments were extracted (QIAquick Gel Extraction kit; Qiagen, Valencia, CA), subcloned (Zero Blunt TOPO PCR cloning kit; Invitrogen, Carlsbad, CA), and confirmed by nucleotide sequencing (Thermo Sequenase Radiolabeled Termination Cycle Sequencing kit; USB, Cleveland, $\mathrm{OH}$ ).

Riboprobes were synthesized using $100 \mathrm{uCi}$ of dried [ $\left.{ }^{35} \mathrm{~S}\right]-\mathrm{UTP}, 2.0 \mu \mathrm{l} 5 \times$ transcription buffer, $1.0 \mu \mathrm{l} 0.1 \mathrm{M}$ DTT, $1.0 \mu \mathrm{l}$ each of $10 \mathrm{mM}$ ATP, CTP, and GTP, $2.0 \mu \mathrm{l}$ linearized plasmid DNA, $0.5 \mu \mathrm{l}$ RNAse inhibitor, and $1.5 \mu 1$ SP6 or T7 RNA polymerase and incubated for $2 \mathrm{~h}$ at $37^{\circ} \mathrm{C}$. After this incubation, $1.0 \mu \mathrm{l}$ DNAse (RNAsefree) was added and incubated for $15 \mathrm{~min}$ at room temperature. The reaction mixture was then sieved through a 1-ml syringe containing G-50 Sephadex equilibrated in Tris buffer (100 mM Tris-HCl, pH 7.5, $12.5 \mathrm{mM}$ EDTA, pH 8.0, $150 \mathrm{mM} \mathrm{NaCl}$, and 0.2\% SDS), and 100$\mu \mathrm{l}$ fractions were eluted. DTT was added to each fraction to a final concentration of $0.01 \mathrm{M}$.

Two slides per subject for each probe were removed from $-80^{\circ} \mathrm{C}$ storage and placed in $4 \%(\mathrm{wt} / \mathrm{vol}$ ) formaldehyde at room temperature for $1 \mathrm{~h}$. The slides were 
Table 1. Summary of Subject Characteristics

\begin{tabular}{lllll}
\hline & Schizophrenia & Bipolar Disorder & Major Depression & Normal Controls \\
\hline$n$ & 15 & 15 & 15 & 15 \\
Age (years) & $44.2(25-62)$ & $42.3(25-61)$ & $46.4(30-65)$ & $48.1(29-68)$ \\
Sex & 9 males, 6 females & 9 males, 6 females & 9 males, 6 females & 9 males, 6 females \\
Race & 13 C, 2A & 14 C, 1AA & 15 C & $14 C, 1 \mathrm{AA}$ \\
PMI (hours) & $33.7(12-61)$ & $32.5(13-62)$ & $27.5(7-47)$ & $23.7(8-42)$ \\
Tissue pH & $6.1(5.8-6.6)$ & $6.2(5.8-6.5)$ & $6.2(5.6-6.5)$ & $6.3(5.8-6.6)$ \\
Side of brain & 6 right, 9 left & 8 right, 7 left & 6 right, 9 left & 7 right, 8 left \\
Suicide & $4 / 15$ & $9 / 15$ & $7 / 15$ & $0 / 15$ \\
ETOH use & $5 / 15$ & $5 / 15$ & $3 / 15$ & $1 / 15$ \\
Medication & $12 / 15$ & $12 / 15$ & $14 / 15$ & $0 / 15$ \\
SSRI & $2 / 15$ & $2 / 15$ & $4 / 15$ & $0 / 15$ \\
Lithium & $2 / 15$ & $4 / 15$ & $2 / 15$ & $0 / 15$ \\
Antipsychotic & $12 / 15$ & $6 / 15$ & $0 / 15$ & $0 / 15$ \\
Other MS & $1 / 15$ & $8 / 15$ & $0 / 15$ & $0 / 15$ \\
\hline
\end{tabular}

C, Caucaisan; AA, African-American; A, Asian; ETOH, ethanol; SSRI, selective serotonin reuptake inhibitor.

${ }^{a}$ History of active ETOH abuse or dependence at time of death.

${ }^{b}$ Treatment with psychotropic medication within 6 weeks of time of death.

${ }^{c}$ Other mood stabilizers: carbamazepine and valproic acid.

briefly washed in $2 \times \mathrm{SSC}(300 \mathrm{mM} \mathrm{NaCl} / 30 \mathrm{mM}$ sodium citrate, $\mathrm{pH}$ 7.2) three times. The slides were placed in $0.1 \mathrm{M}$ triethanolamine, $\mathrm{pH} 8.0$ /acetic anhydride, 400:1 (vol/vol) on a stir plate for $10 \mathrm{~min}$. The final wash was in $2 \times$ SSC buffer for 5 min followed by dehydration through graded alcohols and air drying. A coverslip with $0.5 \mathrm{ml}$ radiolabeled riboprobe $\left(5 \times 10^{6}\right.$ $\mathrm{dpm}), 50 \%$ formamide buffer $(50 \%$ formamide, $10 \%$ dextran sulfate, $3 \times \mathrm{SSC}, 50 \mathrm{mM} \mathrm{Na}_{2} \mathrm{HPO}_{4}$, $\mathrm{pH} 7.4,1 \times$ Denhardt's solution, $100 \mu \mathrm{g} / \mathrm{ml}$ yeast tRNA, $10 \mathrm{mM}$ dithiothreitol), and 0.01 M DTT was placed on each slide. Slides were placed in a covered tray with filter paper saturated with $50 \%$ formamide buffer and incubated at $55^{\circ} \mathrm{C}$ overnight.

The next day, the coverslips were removed and the slides were placed in $2 \times$ SSC for $5 \mathrm{~min}$, followed by RNAse $(200 \mu \mathrm{g} / \mathrm{ml}$ in $10 \mathrm{mM}$ Tris- $\mathrm{HCl}, \mathrm{pH} 8.0 / 0.5 \mathrm{M}$ $\mathrm{NaCl})$ at $37^{\circ} \mathrm{C}$ for $30 \mathrm{~min}$. The slides then underwent the following washes: $2 \times$ SSC at room temperature for 10 $\mathrm{min} ; 1 \times \mathrm{SSC}$ for $10 \mathrm{~min}$ at room temperature; $0.5 \times$ SSC for $10 \mathrm{~min}$ at room temperature; $0.1 \times \mathrm{SSC}$ at $55^{\circ} \mathrm{C}$ for $60 \mathrm{~min}$; a second wash in $0.1 \times \mathrm{SSC}$ at $55^{\circ} \mathrm{C}$ for 60 $\mathrm{min}$; and $0.5 \times$ SSC for $10 \mathrm{~min}$ at room temperature. Sections were dehydrated in graded alcohols and apposed to Kodak BIOMAX MR film for up to 4 weeks.

For each probe, all subjects were run in the same assay to eliminate interassay variability. Sense and antisense probes for EAAT1, EAAT2, EAAT3, and EAAT4 transcripts were tested in sectioned human brain to confirm probe specificity, as previously described (Ibrahim et al. 2000; Meador-Woodruff et al. 1993, 1994). Sections incubated with sense riboprobe or sections pretreated with RNAse before incubation had no significant labeling, whereas sections incubated with antisense probe demonstrated specific labeling.

\section{Data Analysis}

The three striatal regions analyzed in this study (caudate, putamen, and ventral striatum) were identified based on gross morphological patterns. Images were acquired from digitized X-ray films and analyzed with a Macintosh-based imaging system. For digitized images, background-corrected gray scale values for each region were converted to optical density. Background values were obtained for each section from adjacent white matter. Values from two sections for each subject for each probe were averaged and used for statistical analysis. Statistical analysis was performed for each probe by two-way analysis of variance (ANOVA), with diagnosis and striatal region as the independent variables. Post-hoc analyses were by Tukey's HSD test for equal N. For all tests, $\alpha=0.05$.

\section{RESULTS}

We performed in situ hybridization for EAAT mRNA expression on tissue from control subjects and from subjects with schizophrenia, bipolar disorder, and MDD. EAAT1, EAAT2, EAAT3, and EAAT4 transcripts were expressed in all striatal regions studied (Figure 1). There was a main effect for diagnosis for expression of EAAT1 $(\mathrm{F}=2.88, \mathrm{df} 3,162, p=.038)$, EAAT3 $(\mathrm{F}=4.62$, df 3, 149, $p=.004)$, and EAAT4 $(\mathrm{F}=4.69$, df 3, 160, $p=$ .004 ) but not EAAT2 (F = 0.07, df 3, 161, $p=.978$ )(Figure 2). We did not detect significant diagnosis by region interactions for any of the four transporter transcripts. Post-hoc analyses revealed significantly lower levels of mRNA expression for EAAT1 in MDD versus schizophrenia $(p=.024)$, for EAAT3 in bipolar disorder $(p=$ $.002)$ and schizophrenia $(p=.032)$ versus controls, and 


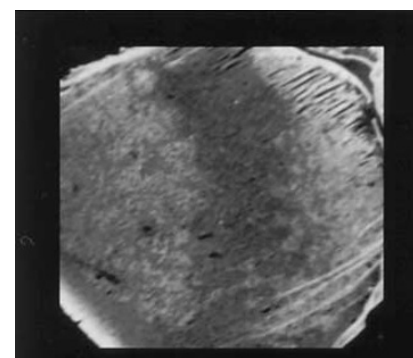

EAAT1

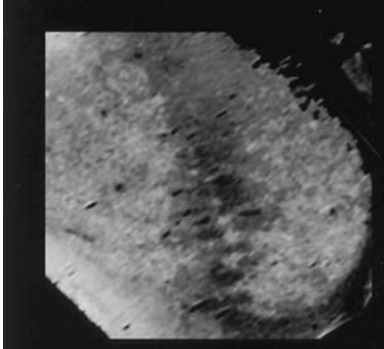

EAAT3

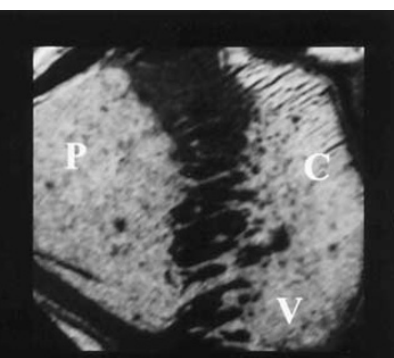

EAAT2
Figure 1. EAAT1, EAAT2, EAAT3, and EAAT4 transcript expression in human striatum. Locations of the caudate $(C)$, putamen $(\mathrm{P})$, and ventral striatum $(\mathrm{V})$ are indicated.

for EAAT4 in bipolar disorder $(p=.010)$ and major depressive disorder $(p=.006)$ versus the control group. We detected a main effect for region for EAAT2 mRNA expression $(\mathrm{F}=18.4, \mathrm{df} 2,161, p<.0001)$. Post-hoc analysis revealed significantly lower levels of EAAT2 mRNA expression in the ventral striatum versus the caudate $(p=.0002)$ and putamen $(p=.001)$ (Figure 2). Analysis of covariance with either $\mathrm{pH}$ or post-mortem interval (PMI) as covariates did not alter any of our primary findings of decreased EAAT3 and/or EAAT4 transcript expression in schizophrenia, bipolar disorder, or MDD.

\section{DISCUSSION}

Recently, glutamatergic dysfunction has been directly implicated in schizophrenia, whereas a small but growing body of literature has suggested a role for abnormal glutamatergic neurotransmission in mood disorders (Auer et al. 2000; Castillo et al. 2000; Gecz et al. 1999; Levine et al. 2000; Meador-Woodruff et al. 2001). Abnormalities in NMDA receptor binding and AMPA receptor subunit mRNA expression have been reported in some studies in the striatum in schizophrenia and bipolar disorder, supporting a hypothesis of glutamatergic dysfunction in subcortical structures (AparicioLegarza et al. 1998; Kornhuber et al. 1989; MeadorWoodruff et al. 2001; Noga et al. 1997). Recent work has directly implicated abnormalities of EAAT mRNA ex-
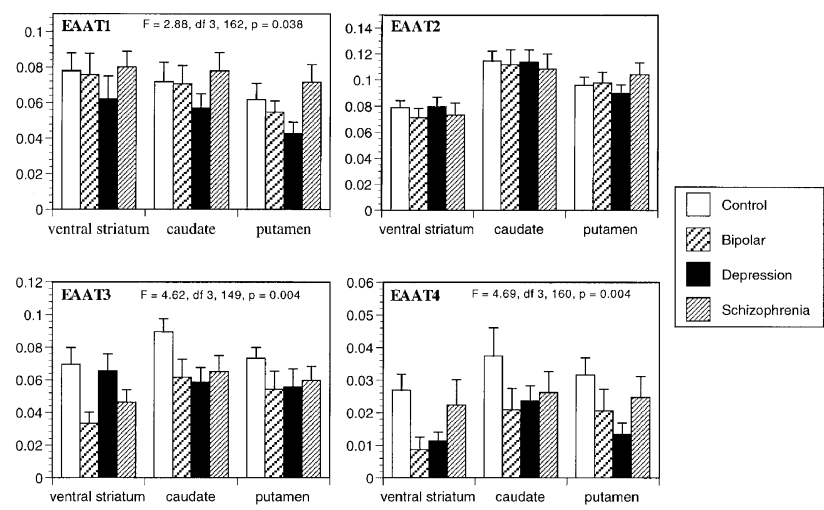

Figure 2. EAAT1, EAAT2, EAAT3, and EAAT4 mRNA expression in striatal regions in schizophrenia, bipolar disorder, MDD, and control subjects. Data are expressed as means \pm SEM. Post-hoc analyses for diagnosis are as follows: EAAT1, MDD versus schizophrenia $(p=.024)$; EAAT3, bipolar disorder $(p=.002)$ and schizophrenia $(p=.032)$ versus control group; and EAAT4, bipolar disorder $(p=.010)$ and $\operatorname{MDD}(p=$ .006) versus the control group.

pression in the prefrontal cortex and thalamus in schizophrenia (Ohnuma et al. 1998; Smith et al. 2001). Thus, we hypothesized that alterations in EAAT expression may be found in the striatum in schizophrenic and mood disordered subjects. In this study, we evaluated striatal expression of the EAATs, a family of molecules responsible for maintaining appropriate synaptic glutamate levels via transport of glutamate into neurons or glia. We detected significant alterations in EAAT mRNA expression in the striatum of subjects with mood disorders (EAAT3 and EAAT4) and schizophrenia (EAAT3)(Figure 2)

Recent work has implicated the glutamate neurotransmitter system in bipolar disorder. An increased glutamate plus glutamine level was detected in the basal ganglia of children with bipolar disorder by magnetic resonance spectroscopy (Castillo et al. 2000). Whereas this study does not indicate whether the increase in the glutamate metabolite level is in the presynaptic releasable neurotransmitter pool, the synapse, postsynaptic neurons or glia, or in intermediary metabolism, such an observation is consistent with our finding of decreased striatal EAAT mRNA expression in bipolar disorder. A decrease in EAAT3 and/or EAAT4 expression may diminish the capacity of the synapse to clear glutamate, resulting in increased levels of glutamate and its metabolites in the synapse.

We have recently reported increased expression of EAAT1 and EAAT2 mRNA and alterations in NMDA receptor subunit expression and binding in the thalamus in schizophrenia (Ibrahim et al. 2000; Smith et al. 2001). The observation of decreased striatal EAAT3 mRNA expression in schizophrenia extends the growing body of literature supporting a glutamatergic dys- 
function hypothesis in schizophrenia and emphasizes that abnormalities of the glutamate system involve molecules other than the glutamate receptors.

Previously, several preclinical studies have implicated the NMDA receptor in the pathophysiology of affective disorders (Nowak et al. 1993; Skolnick et al. 1996; Trullas and Skolnick 1990; Trullas et al. 1991;Viu et al. 1998; Winslow et al. 1990). More recently, NMDA receptors were directly implicated in a clinical study that demonstrated an improvement in depressive symptomatology after treatment with an NMDA receptor antagonist (Berman et al. 2000). However, few studies have detailed abnormalities of glutamate physiology in MDD, and little is known regarding alterations in glutamate reuptake and metabolism in major depression (Auer et al. 2000; Levine et al. 2000). We have detected decreased EAAT4 mRNA expression in MDD, suggesting a role for abnormal postsynaptic glutamate reuptake in this illness.

We have detected significant alterations in EAAT3 and/or EAAT4 mRNA expression in the striatum in schizophrenia and mood disorders. Because EAAT3 and EAAT4 are expressed in neurons whereas EAAT1 and EAAT2 are expressed in astroglia, our results suggest an abnormality associated with neurons, but not astroglia, in the glutamate synapse (Bar-Peled et al. 1997; Chaudhry et al. 1995; Furuta et al. 1997; Lehre et al. 1995; Milton et al. 1997; Rothstein et al. 1994; Yamada et al. 1996, 1997). Interestingly, we have previously reported abnormalities in EAAT1 and EAAT2, but not EAAT3 or EAAT4, mRNA expression in the thalamus, a finding consistent with the notion of localization of glutamatergic abnormalities within the synapse to specific cell types in given brain regions (Smith et al. 2001).

One possible limitation of this study is the putative effects of psychotropic medications on striatal EAAT expression. Due to an inadequate number of subjects receiving a given medication, we were unable to perform statistical analysis to evaluate the influence of psychotropic medications on EAAT mRNA expression. Our findings in subjects with bipolar disorder are potentially confounded by the presence of mood stabilizer treatment, because valproic acid has been reported to increase synaptic glutamate levels in rodent cortical slices and glutamate reuptake is directly blocked by lithium in rodent cortical synaptosomes (Dixon and Hokin 1997, 1998). In addition, our finding of decreased EAAT3 transcript expression in schizophrenic subjects could be confounded by medication treatment, because striatal EAAT2 mRNA expression and uptake of D- $\left[{ }^{3} \mathrm{H}\right]$ aspartate in rat striatal synaptosomes are both decreased in rats treated with antipsychotics (De Souza et al. 1999; Melone et al. 2001; Schneider et al. 1998). In these studies of antipsychotic effects, EAAT3 and EAAT4 transcript expression was not evaluated. Effects of antidepressant medication on EAAT expression have not previously been reported. Although there is no direct evidence that our findings of altered neuronal EAAT expression in the striatum are secondary to a medication effect, this remains a possibility.

In this study, we have detected decreased EAAT3 and EAAT4 mRNA expression in bipolar disorder and decreased EAAT4 mRNA expression in MDD, suggesting a role for glutamatergic dysfunction in the pathophysiology of mood disorders. In addition, we detected decreased EAAT3 mRNA expression in schizophrenia, extending previous findings of glutamatergic abnormalities in this illness. Based on the previously reported distribution of EAAT mRNA and protein expression, our findings of decreased EAAT3 and EAAT4 mRNA expression suggest a neuron-specific glutamatergic abnormality in the striatum, contrasted with our recent finding of abnormalities in glial glutamate transporters (EAAT1 and EAAT2) in the thalamus in schizophrenia (Smith et al. 2001). These results extend the body of evidence implicating abnormal glutamatergic neurotransmission in schizophrenia and provide novel evidence of putative alterations in glutamate neurotransmission in mood disorders.

\section{ACKNOWLEDGMENTS}

This work was supported by grant number MH53327 (JHM-W) from NIMH. Postmortem brains were donated by the Stanley Foundation Brain Bank, courtesy of Drs. Michael Knable, E. Fuller Torrey, Maree J. Webster, and Robert H. Yolken. RES was supported by the Pfizer/University of Michigan Residency Research Track Fellowship.

\section{REFERENCES}

Akbarian S, Sucher NJ, Bradley D, Tafazzoli A, Trinh D, Hetrick WP, Potkin SG, Sandman CA, Bunney WE Jr, Jones EG (1996): Selective alterations in gene expression for NMDA receptor subunits in prefrontal cortex of schizophrenics. J Neurosci 16:19-30

Aparicio-Legarza MI, Davis B, Hutson PH, Reynolds GP (1998): Increased density of glutamate/N-methylD-aspartate receptors in putamen from schizophrenic patients. Neurosci Lett 241:143-146

Arriza JL, Kavanaugh MP, Fairman WA, Wu YN, Murdoch GH, North RA, Amara SG (1993): Cloning and expression of a human neutral amino acid transporter with structural similarity to the glutamate transporter gene family. J Biol Chem 268:15329-15332

Arriza JL, Eliasof S, Kavanaugh MP, Amara SG (1997): Excitatory amino acid transporter 5, a retinal glutamate transporter coupled to a chloride conductance. Proc Natl Acad Sci USA 94:4155-4160

Arzberger T, Krampfl K, Leimgruber S, Weindl A (1997): Changes of NMDA receptor subunit (NR1, NR2B) and 
glutamate transporter (GLT1) mRNA expression in Huntington's disease-An in situ hybridization study. J Neuropathol Exp Neurol 56:440-454

Auer DP, Putz B, Kraft E, Lipinski B, Schill J, Holsboer F (2000): Reduced glutamate in the anterior cingulate cortex in depression: An in vivo proton magnetic resonance spectroscopy study. Biol Psychiatry 47:305-313

Bar-Peled O, Ben-Hur H, Biegon A, Groner Y, Dewhurst S, Furuta A, Rothstein JD (1997): Distribution of glutamate transporter subtypes during human brain development. J Neurochem 69:2571-2580

Berman RM, Cappiello A, Anand A, Oren DA, Heninger GR, Charney DS, Krystal JH (2000): Antidepressant effects of ketamine in depressed patients. Biol Psychiatry 47:351-354

Castillo M, Kwock L, Courvoisie H, Hooper SR (2000): Proton MR spectroscopy in children with bipolar affective disorder: Preliminary observations. Am J Neuroradiol 21:832-838

Chaudhry FA, Lehre KP, van Lookeren Campagne M, Ottersen OP, Danbolt NC, Storm-Mathisen J (1995): Glutamate transporters in glial plasma membranes: Highly differentiated localizations revealed by quantitative ultrastructural immunocytochemistry. Neuron 15:711-720

Deakin JF, Slater P, Simpson MD, Gilchrist AC, Skan WJ, Royston MC, Reynolds GP, Cross AJ (1989): Frontal cortical and left temporal glutamatergic dysfunction in schizophrenia. J Neurochem 52:1781-1786

De Souza IE, McBean GJ, Meredith GE (1999): Chronic haloperidol treatment impairs glutamate transport in the rat striatum. Eur J Pharmacol 382:139-142

Dixon JF, Hokin LE (1997): The antibipolar drug valproate mimics lithium in stimulating glutamate release and inositol 1,4,5-trisphosphate accumulation in brain cortex slices but not accumulation of inositol monophosphates and bisphosphates. Proc Natl Acad Sci USA 94:4757-4760

Dixon JF, Hokin LE (1998): Lithium acutely inhibits and chronically up-regulates and stabilizes glutamate uptake by presynaptic nerve endings in mouse cerebral cortex. Proc Natl Acad Sci USA 95:8363-8368

Eastwood SL, McDonald B, Burnet PW, Beckwith JP, Kerwin RW, Harrison PJ (1995): Decreased expression of mRNAs encoding non-NMDA glutamate receptors GluR1 and GluR2 in medial temporal lobe neurons in schizophrenia. Brain Res Mol Brain Res 29:211-223

Eastwood SL, Burnet PW, Harrison PJ (1997a): GluR2 glutamate receptor subunit flip and flop isoforms are decreased in the hippocampal formation in schizophrenia: A reverse transcriptase-polymerase chain reaction (RT-PCR) study. Brain Res Mol Brain Res 44:92-98

Eastwood SL, Kerwin RW, Harrison PJ (1997b): Immunoautoradiographic evidence for a loss of alpha-amino3-hydroxy-5-methyl-4-isoxazole propionate-preferring non-N-methyl-D-aspartate glutamate receptors within the medial temporal lobe in schizophrenia. Biol Psychiatry 41:636-643

Fray AE, Ince PG, Banner SJ, Milton ID, Usher PA, Cookson MR, Shaw PJ (1998): The expression of the glial glutamate transporter protein EAAT2 in motor neuron disease: An immunohistochemical study. Eur J Neurosci 10:2481-2489

Furuta A, Martin LJ, Lin CL, Dykes-Hoberg M, Rothstein JD (1997): Cellular and synaptic localization of the neuronal glutamate transporters excitatory amino acid transporter 3 and 4. Neuroscience 81:1031-1042

Gecz J, Barnett S, Liu J, Hollway G, Donnelly A, Eyre H, Eshkevari HS, Baltazar R, Grunn A, Nagaraja R, Gilliam C, Peltonen L, Sutherland GR, Baron M, Mulley JC (1999): Characterization of the human glutamate receptor subunit 3 gene (GRIA3), a candidate for bipolar disorder and nonspecific X-linked mental retardation. Genomics 62:356-368

Grimwood S, Slater P, Deakin JF, Hutson PH (1999): NR2Bcontaining NMDA receptors are up-regulated in temporal cortex in schizophrenia. Neuroreport 10:461-465

Harrison PJ, McLaughlin D, Kerwin RW (1991): Decreased hippocampal expression of a glutamate receptor gene in schizophrenia. Lancet 337:450-452

Healy DJ, Haroutunian V, Powchik P, Davidson M, Davis KL, Watson SJ, Meador-Woodruff JH (1998): AMPA receptor binding and subunit mRNA expression in prefrontal cortex and striatum of elderly schizophrenics. Neuropsychopharmacology 19:278-286

Humphries C, Mortimer A, Hirsch S, de Belleroche J (1996): NMDA receptor mRNA correlation with antemortem cognitive impairment in schizophrenia. Neuroreport 7:2051-2055

Ibrahim HM, Hogg AJ, Healy DJ, Haroutunian V, Davis KL, Meador-Woodruff JH (2000): Ionotropic glutamate receptor binding and subunit mRNA expression in thalamic nuclei in schizophrenia. Am J Psychiatry 157:1811-1823

Kerwin RW, Patel S, Meldrum BS, Czudek C, Reynolds GP (1988): Asymmetrical loss of glutamate receptor subtype in left hippocampus in schizophrenia. Lancet 1:583-584

Kerwin R, Patel S, Meldrum B (1990): Quantitative autoradiographic analysis of glutamate binding sites in the hippocampal formation in normal and schizophrenic brain post mortem. Neuroscience 39:25-32

Kornhuber J, Mack-Burkhardt F, Riederer P, Hebenstreit GF, Reynolds GP, Andrews HB, Beckmann H (1989): [3H]MK-801 binding sites in postmortem brain regions of schizophrenic patients. J Neural Transm 77:231-236

Lehre KP, Levy LM, Ottersen OP, Storm-Mathisen J, Danbolt NC (1995): Differential expression of two glial glutamate transporters in the rat brain: Quantitative and immunocytochemical observations. J Neurosci 15:1835-1853

Levine J, Panchalingam K, Rapoport A, Gershon S, McClure RJ, Pettegrew JW (2000): Increased cerebrospinal fluid glutamine levels in depressed patients. Biol Psychiatry 47:586-593

Lin CL, Bristol LA, Jin L, Dykes-Hoberg M, Crawford T, Clawson L, Rothstein JD (1998): Aberrant RNA processing in a neurodegenerative disease: The cause for absent EAAT2, a glutamate transporter, in amyotrophic lateral sclerosis. Neuron 20:589-602

Meador-Woodruff JH, Healy DJ (2000): Glutamate receptor expression in schizophrenic brain. Brain Res Rev 31: 288-294 
Meador-Woodruff JH, Little KY, Damask SP, Mansour A, Watson SJ (1993): Effects of cocaine on dopamine receptor gene expression: A study in the postmortem human brain. Biol Psychiatry 34:348-355

Meador-Woodruff JH, Grandy DK, Van Tol HH, Damask SP, Little KY, Civelli O, Watson SJ Jr (1994): Dopamine receptor gene expression in the human medial temporal lobe. Neuropsychopharmacology 10:239-248

Meador-Woodruff JH, Hogg AJ Jr, Smith RE (2001): Striatal ionotropic glutamate receptor expression in schizophrenia, bipolar disorder, and major depressive disorder. Brain Res Bull 55:631-640

Melone M, Vitellaro-Zuccarello L, Vallejo-Illarramendi A, Perez-Samartin A, Matute C, Cozzi A, PellegriniGiampietro DE, Rothstein JD, Conti F (2001): The expression of glutamate transporter GLT-1 in the rat cerebral cortex is down-regulated by the antipsychotic drug clozapine. Mol Psychiatry 6:380-386

Meyer T, Munch C, Volkel H, Booms P, Ludolph AC (1998): The EAAT2 (GLT-1) gene in motor neuron disease: Absence of mutations in amyotrophic lateral sclerosis and a point mutation in patients with hereditary spastic paraplegia. J Neurol Neurosurg Psychiatry 65: 594-596

Meyer T, Fromm A, Munch C, Schwalenstocker B, Fray AE, Ince PG, Stamm S, Gron G, Ludolph AC, Shaw PJ (1999): The RNA of the glutamate transporter EAAT2 is variably spliced in amyotrophic lateral sclerosis and normal individuals. J Neurol Sci 170:45-50

Milton ID, Banner SJ, Ince PG, Piggott NH, Fray AE, Thatcher N, Horne CH, Shaw PJ (1997): Expression of the glial glutamate transporter EAAT2 in the human CNS: An immunohistochemical study. Brain Res Mol Brain Res 52:17-31

Nishikawa T, Takashima M, Toru M (1983): Increased $[3 \mathrm{H}]$ kainic acid binding in the prefrontal cortex in schizophrenia. Neurosci Lett 40:245-250

Noga JT, Hyde TM, Herman MM, Spurney CF, Bigelow LB, Weinberger DR, Kleinman JE (1997): Glutamate receptors in the postmortem striatum of schizophrenic, suicide, and control brains. Synapse 27:168-176

Nowak G, Trullas R, Layer RT, Skolnick P, Paul IA (1993): Adaptive changes in the $\mathrm{N}$-methyl-D-aspartate receptor complex after chronic treatment with imipramine and 1-aminocyclopropanecarboxylic acid. J Pharmacol Exp Ther 265:1380-1386

Ohnuma T, Augood SJ, Arai H, McKenna PJ, Emson PC (1998): Expression of the human excitatory amino acid transporter 2 and metabotropic glutamate receptors 3 and 5 in the prefrontal cortex from normal individuals and patients with schizophrenia. Brain Res Mol Brain Res 56:207-217

Porter RH, Eastwood SL, Harrison PJ (1997): Distribution of kainate receptor subunit mRNAs in human hippocampus, neocortex and cerebellum, and bilateral reduction of hippocampal GluR6 and KA2 transcripts in schizophrenia. Brain Res 751:217-231

Rothstein JD, Martin L, Levey AI, Dykes-Hoberg M, Jin L, Wu D, Nash N, Kuncl RW (1994): Localization of neuronal and glial glutamate transporters. Neuron 13:713-725

Rothstein JD, Dykes-Hoberg M, Pardo CA, Bristol LA, Jin L,
Kuncl RW, Kanai Y, Hediger MA, Wang Y, Schielke JP, Welty DF (1996): Knockout of glutamate transporters reveals a major role for astroglial transport in excitotoxicity and clearance of glutamate. Neuron 16:675-686

Schneider JS, Wade T, Lidsky TI (1998): Chronic neuroleptic treatment alters expression of glial glutamate transporter GLT-1 mRNA in the striatum. Neuroreport 9:133-136

Sims KD, Robinson MB (1999): Expression patterns and regulation of glutamate transporters in the developing and adult nervous system. Crit Rev Neurobiol 13:169-197

Skolnick P, Layer RT, Popik P, Nowak G, Paul IA, Trullas R (1996): Adaptation of N-methyl-D-aspartate (NMDA) receptors following antidepressant treatment: Implications for the pharmacotherapy of depression. Pharmacopsychiatry 29:23-26

Smith RE, Haroutunian V, Davis KL, Meador-Woodruff JH (2001): Expression of excitatory amino acid transporter transcripts in the thalamus in schizophrenia. Am J Psychiatry 158:1393-1399

Sokolov BP (1998): Expression of NMDAR1, GluR1, GluR7, and KA1 glutamate receptor mRNAs is decreased in frontal cortex of "neuroleptic-free" schizophrenics: Evidence on reversible up-regulation by typical neuroleptics. J Neurochem 71:2454-2464

Tanaka K, Watase K, Manabe T, Yamada K, Watanabe M, Takahashi K, Iwama H, Nishikawa T, Ichihara N, Kikuchi T, Okuyama S, Kawashima N, Hori S, Takimoto M, Wada K (1997): Epilepsy and exacerbation of brain injury in mice lacking the glutamate transporter GLT-1. Science 276:1699-1702

Torrey EF, Webster M, Knable M, Johnston N, Yolken RH (2000): The Stanley foundation brain collection and neuropathology consortium. Schizophr Res 44:151-155

Trullas R, Skolnick P (1990): Functional antagonists at the NMDA receptor complex exhibit antidepressant actions. Eur J Pharmacol 185:1-10

Trullas R, Folio T, Young A, Miller R, Boje K, Skolnick P (1991): 1-aminocyclopropanecarboxylates exhibit antidepressant and anxiolytic actions in animal models. Eur J Pharmacol 203:379-385

Utsunomiya-Tate N, Endou H, Kanai Y (1996): Cloning and functional characterization of a system ASC-like Na+dependent neutral amino acid transporter. J Biol Chem 271:14883-14890

Viu E, Zapata A, Capdevila JL, Fossom LH, Skolnick P, Trullas R (1998): Glycine site antagonists and partial agonists inhibit N-methyl-D-aspartate receptor-mediated [3H]arachidonic acid release in cerebellar granule cells. J Pharmacol Exp Ther 285:527-532

Watase K, Hashimoto K, Kano M, Yamada K, Watanabe M, Inoue Y, Okuyama S, Sakagawa T, Ogawa S, Kawashima N, Hori S, Takimoto M, Wada K, Tanaka K (1998): Motor discoordination and increased susceptibility to cerebellar injury in GLAST mutant mice. Eur J Neurosci 10:976-988

Winslow JT, Insel TR, Trullas R, Skolnick P (1990): Rat pup isolation calls are reduced by functional antagonists of the NMDA receptor complex. Eur J Pharmacol 190: 11-21 
Yamada K, Watanabe M, Shibata T, Tanaka K, Wada K, Inoue Y (1996): EAAT4 is a post-synaptic glutamate transporter at Purkinje cell synapses. Neuroreport 7:2013-2017
Yamada K, Wada S, Watanabe M, Tanaka K, Wada K, Inoue $Y$ (1997): Changes in expression and distribution of the glutamate transporter EAAT4 in developing mouse Purkinje cells. Neurosci Res 27:191-198 